\title{
Gavarilla, a new genus of jumping spider from Brazil, and description of two new species of the genera Capeta Ruiz \& Brescovit and Amatorculus Ruiz \& Brescovit (Araneae, Salticidae, Sitticinae)
}

\author{
Gustavo R. S. Ruiz \& Antonio D. Brescovit
}

Laboratório de Artrópodes, Instituto Butantan. Avenida Vital Brazil 1500, 05503-900 São Paulo, São Paulo, Brasil. E-mail: gustavoruiz86@hotmail.com,adbresc@terra.com.br

\begin{abstract}
Gavarilla gen. nov. from Northeastern Brazil is proposed to include two new species: the type species Gavarilla ianuzziae sp. nov. from the State of Sergipe and Gavarilla arretada sp. nov. from the State of Maranhão. The genus presents the standard sitticine dentition and is presumably related to the genera Aillutticus Galiano, 1987, Nosferattus Ruiz \& Brescovit, 2005, Capeta Ruiz \& Brescovit, 2005 and Amatorculus Ruiz \& Brescovit, 2005, with which it shares the similar high, rounded carapace. Two new species, Capeta cachimbo and Amatorculus cristinae, are also described from the State of Pará, and Amatorculus stygius Ruiz \& Brescovit, 2005 is recorded for the first time from the State of Minas Gerais.
\end{abstract}

KEY WORDS. Neotropical Region; systematics; taxonomy.

\begin{abstract}
RESUMO. Gavarilla, um novo gênero de aranha papa-mosca do Brasil, e descrição de duas espécies novas dos gêneros Capeta Ruiz \& Brescovit, 2005 e Amatorculus Ruiz \&x Brescovit (Araneae, Salticidae, Sitticinae). Gavarilla gen. nov. do Nordeste do Brasil é proposto para incluir duas espécies novas: a espécie-tipo Gavarilla ianuzziae sp. nov. de Sergipe e Gavarilla arretada sp. nov. do Maranhão. O gênero apresenta a dentição padrão dos siticíneos e está provavelmente relacionado aos gêneros Aillutticus Galiano, 1987, Nosferattus Ruiz \& Brescovit, 2005, Capeta Ruiz \& Brescovit, 2005 e Amatorculus Ruiz \& Brescovit, 2005, com os quais compartilha a carapaça alta e arredondada. Duas espécies novas, Capeta cachimbo e Amatorculus cristinae, também são descritas para o Pará, e Amatorculus stygius Ruiz \& Brescovit, 2005 é registrado pela primeira vez para o Estado de Minas Gerais.

PALAVRAS-CHAVE. Região Neotropical; sistemática; taxonomia.
\end{abstract}

The Sitticinae lineage is still poorly understood in the Neotropical Region. Galiano (1987) foresaw the increase in knowledge of the diversity of this group in South America, which has been corroborated by Ruiz \& Brescovit (2005), who revealed the existence of several previously unknown lineages of neotropical sitticines.

The subfamily is characterized by the absence of retromarginal teeth on the chelicerae and presently comprises in the Neotropical Region the genera Sitticus Simon, 1901, Jollas Simon, 1901, Semiopyla Simon, 1901, Pseudattulus Caporiacco, 1947, Aillutticus Galiano, 1987, Nosferattus Ruiz \& Brescovit, 2005, Capeta Ruiz \& Brescovit, 2005 and Amatorculus Ruiz \& Brescovit, 2005. In addition to these genera, we here propose the new genus Gavarilla from Northeastern Brazil. This genus presents the standard sitticine dentition and is presumably related to Aillutticus, Nosferattus, Capeta and Amatorculus, with which it shares a high, broad carapace, laterally rounded behind the posterior lateral eyes, and the slightly convex dorsal surface of the cephalic region (GALIANO 1987: figs 1-2), but differs mainly by the exclusive genital morphology. The new genus includes two species herein described, G. ianuzziae sp. nov. from the State of Sergipe and G. arretada sp. nov. from the State of Maranhão, both in Brazil.

In addition, we present the descriptions of Capeta cachimbo sp. nov. and Amatorculus cristinae sp. nov., both from the Serra do Cachimbo, State of Pará, Northern Brazil, and the first record of Amatorculus stygius Ruiz \& Brescovit, 2005 from the State of Minas Gerais, Southeastern Brazil.

\section{MATERIAL AND METHODS}

The material examined is deposited in the following institutions (abbreviation and curator in parentheses): Instituto Butantan (IBSP, A.D. Brescovit); Museu Paraense Emílio Goeldi (MPEG, A.B. Bonaldo); Museu de Zoologia da Universidade de São Paulo (MZSP, R. Pinto da Rocha). The measurements are given in millimeters. The abbreviations used throughout the 
text are: (RTA) retrolateral tibial apophysis, (VTA) ventral tibial apophysis, (PLE) posterior lateral eyes, (d) dorsal, (p) prolateral, (r) retrolateral, (v) ventral, (pr) proximal, (di) distal.

\section{Gavarilla gen. nov.}

Type species: Gavarilla ianuzziae sp. nov.

Etymology. The generic name is an arbitrary combination of letters. The grammatical gender is feminine.

Diagnosis. Species of the genus Gavarilla can be distinguished from the remaining sitticine genera by the two developed strong spines on the RTA of the male palp (Figs 1-2 and 56 ) and by the U-shaped median atrium on the epigynal plate of the female (Figs 3, 7).

Description. Small spiders (males 3.00-3.90 long, females 3.55-5.00 long), carapace high, broad, laterally rounded behind the PLE (GALIANo 1987: figs 1-2), dorsal surface of the cephalic region slightly convex. Chelicera small, conical, vertical, parallel, with four teeth on promargin, none on retromargin, nor any other modifications on either sex. Endite rectangular, with no conspicuous projection. Male palp with a small and spherical cymbium, embolus short, distal and tangential to the tegulum, RTA bifid, with short branches bearing two developed strong spines and a VTA elongated and directed retrolaterally (Figs 1-2 and 5-6). Patella I, tibia I and metatarsus I ventrally covered by a dense fringe of long black hairs. Spinulation. Male: femur I d1-1-1, p1di, r2di, II, III, IV d1-1-1, p2di, r2di; patella I, II, III, IV p1, r1; tibia I p1-1-1, v2di (at least), II d1, v1r-1r-2, p11-1, r1-1-1, III, IV d1pr, v1p-0-2, p1-1-1, r1-1-1; metatarsus I v22 (at least), II v2-2, p1-1, r1-1, III d1pr, v2-2, p1-2, r1-2, IV d1pr, v1p-1p, p1-1-2, r1-1-2. Female: femur I d1-1-1, p1di, r1di, II d11-1, p2di, r2di, III d1-1-1, p2di, r1di, IV d1-1-1, p2di, r2di; patella I, II 0, III, IV p1, r1; tibia I, II v1r-1r-1p, p1-1, III d1pr, v1p0-2, p1-1-1, r1-1, IV d1pr, v1p-0-2, p1-1-1, r1-1-1; metatarsus I, II v2-2, p1-1, III d1pr, v1p-2, p1-2, r1-2, IV d1pr, v1p-1p, p1-1-2, r1-1-2. Abdomen dorsally covered by an anterior smooth oval scutum in males. Female epigynum with a median U-shaped atrium and sinuous epigynal plate posteriorly (Figs 3, 7). Internally with long and sinuous copulation ducts, large spermathecae and apical elongated fertilization ducts (Figs 4, 8).

Comments. The fringe of long black hairs on the patella, tibia and metatarsus of leg I renders difficult the observation of ventral spines of these segments.

Distribution. Known only from Northeastern Brazil (Maranhão and Sergipe).

\section{Gavarilla ianuzziae sp. nov. Figs $1-4$}

Types. Male holotype from BraziL, Sergipe: Canindé do São Francisco (Fazenda São José, Usina Hidrelétrica de Xingó), 26.X.2000, L. Ianuzzi leg. (IBSP 51382); two female paratypes with the same data as holotype (IBSP 51379; 51381).

Etymology. The species is named in honour of Luciana
Ianuzzi, who collected the type specimens.

Diagnosis. Specimens of Gavarilla ianuzziae sp. nov. differ from those of $G$. arretada sp. nov. by the larger projection on the prolateral base of the embolus and by the longer VTA in the male palp (Figs 1-2). Females can be distinguished from those of $G$. arretada by the excavated posterior border of the epigynal plate and by the close set spermathecae (Figs 3-4).

Description. Male. Total length: 3.45. Carapace dark brown, slightly variegated, 1.75 long, 1.35 wide, 0.90 high, with a pair of white stripes extending from the PLE to the posterior edge of the carapace. Ocular quadrangle 0.85 long. Anterior eye row 1.25 wide and posterior 1.22 wide. Cephalic region covered with white hairs; long brown hairs around the anterior eyes. Chelicera light brown, with four teeth on promargin. Endite, labium and sternum light brown. Palp yellow, with a dorsal narrow dark stripe; embolus spade-shaped; sinuous spines on RTA (Figs 1-2). Legs 4123 yellow, with a median brown spot prolaterally and ventrally on distal femur I. Patella I, tibia I and metatarsus I light brown, ventrally covered by a dense fringe of long black hairs. Femur IV with a median dark ring and tibia IV distally dark. Length of femur: I 0.80 , II 0.80 , III 0.80 , IV 1.35; patella + tibia: I 1.00, II 0.95, III 0.85, IV 1.50; metatarsus + tarsus: I 0.75 , II 0.75 , III 0.80 , IV 1.15. Abdomen dorsally dark brown, laterally and ventrally cream, covered by a dark brown scutum and white hairs dorsally. Anterior spinnerets yellow, posterior light brown.

Female. Total length: 3.80. Carapace light brown, 1.75 long, 1.45 wide, 1.05 high. Ocular quadrangle 0.95 long. Anterior eye row 1.25 wide and posterior 1.25 wide. Carapace with a longitudinal median dark stripe extending from between the PLE to the posterior edge, laterally covered with white hairs and dorsally with long brown hairs, mainly around eyes. Clypeus densely covered with long white hairs. Chelicera yellow, with four teeth on promargin. Endite, labium and sternum yellow. Palp yellow. Legs $41=32$ yellow, with light brown rings. Length of femur: I 0.85, II 0.80, III 0.85, IV 1.55; patella + tibia: I 1.00, II 0.95, III 0.90, IV 1.70; metatarsus + tarsus: I 0.75 , II 0.75 , III 0.85 , IV 1.20 . Abdomen dorsally dark brown, with a pair of small cream spots on anterior half and a pair of larger pale spots on the posterior half; slightly conspicuous chevrons extending from among these four cream spots to the posterior edge of abdomen; laterally and ventrally cream colored. Epigynum with a median atrium and sinuous copulation ducts (Figs 3-4). Spinnerets as in the male.

Variation. Six females: total length: 3.55-4.35; carapace length: 1.75-1.95.

Additional material examined. BRAzIL, Sergipe: Canindé do São Francisco (Fazenda São José, Usina Hidrelétrica de Xingó), four females, III-X.2000, L. Ianuzzi leg. (IBSP 5137751378; 51380).

Distribution. Known only from the State of Sergipe, Brazil.

Natural history. The material examined was collected with

Revista Brasileira de Zoologia 23 (2): 350-356, junho 2006 

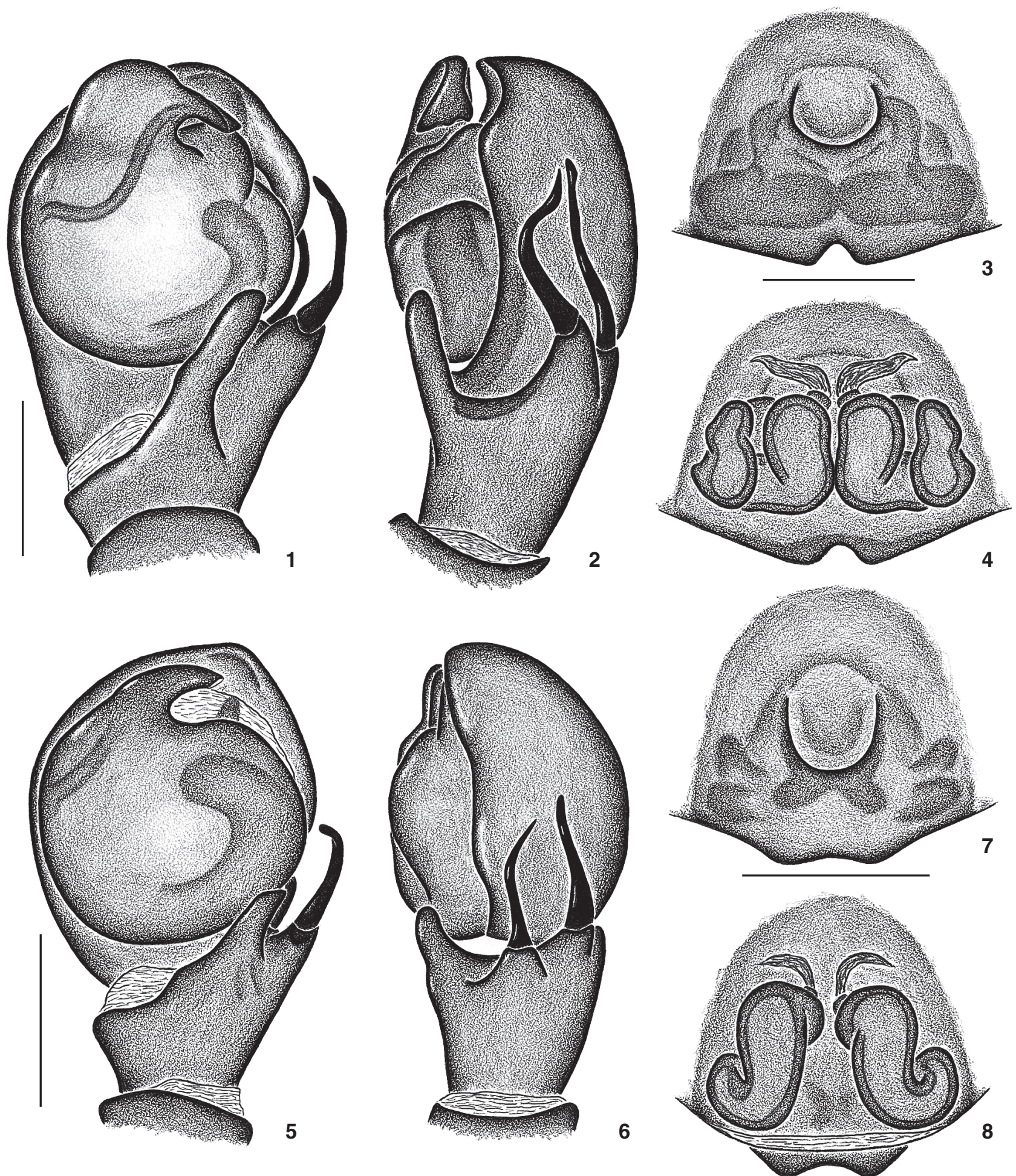

Figures 1-8. (1-4) Gavarilla ianuzziae sp. nov.: (1) male palp, ventral view, (2) retrolateral view; (3) epigynum, ventral view; (4) dorsal view; (5-8) Gavarilla arretada sp. nov.: (5) male palp, ventral view; (6) retrolateral view; (7) epigynum, ventral view; (8) dorsal view. Scale lines: $0.25 \mathrm{~mm}$.

Revista Brasileira de Zoologia 23 (2): 350-356, junho 2006 
pitfall traps in the Brazilian Caatinga, a phytogeographic region characterized by a very hot, semi-arid climates with temperatures above $40^{\circ} \mathrm{C}$ and plants which present characteristics associated with water conservation (FERNANDEs 1998, Joly et al. 1999).

\section{Gavarilla arretada sp. nov.} Figs 5-8

Types. Male holotype from BraziL, Maranhão: Barreirinhas, (Parque Nacional dos Lençóis Maranhenses, 244'49"S, $42^{\circ} 49^{\prime} 39^{\prime \prime} \mathrm{W}$ ), 12-18.X.2001, Equipe Biota leg. (IBSP 51394); two male and three female paratypes with the same data as holotype (IBSP 51383; 51389; 51395; MZSP).

Etymology. The specific name is a regional adjective used in the State of Maranhão that means "well made".

Diagnosis. Specimens of Gavarilla arretada sp. nov. differ from those of $G$. ianuzziae sp. nov. by the smaller projection at the prolateral base of the embolus and by the shorter VTA in the male palp (Figs 5-6). Females can be distinguished from those of G. ianuzziae sp. nov. by the sinuous posterior border of the epigynal plate and by the farther set spermathecae (Figs 7-8).

Description. Male. Total length: 3.00. Carapace dark brown, 1.75 long, 1.35 wide, 0.95 high, with a pair of white stripes extending from the PLE to the posterior edge of the carapace. Ocular quadrangle 0.90 long. Anterior eye row 1.25 wide and posterior 1.22 wide. Chelicera yellow, with four teeth on promargin. Endite, labium and sternum yellow. Palp yellow, embolus acute and sinuous spines on RTA (Figs 5-6). Legs $412=3$ yellow, with dark rings. Patella I, tibia I and metatarsus I light brown, ventrally covered by a dense fringe of long black hairs. Length of femur: I 0.80, II 0.80, III 0.80, IV 1.50; patella + tibia: I 1.00, II 0.95, III 0.90, IV 1.60; metatarsus + tarsus: I 0.80, II 0.80, III 0.85 , IV 1.15. Abdomen light brown, covered by a dark brown dorsal scutum. Anterior spinnerets yellow, posterior light brown.

Female. Total length: 5.00. Carapace light brown, 2.10 long, 1.55 wide, 1.00 high. Ocular quadrangle 0.95 long. Anterior eye row 1.35 wide and posterior 1.40 wide. Carapace with a longitudinal median dark stripe extending from the PLE to the posterior edge, laterally covered with white hairs and dorsally with long brown hairs. Chelicera yellow, with four teeth on promargin. Endite, labium and sternum yellow. Palp yellow. Legs 4312 yellow, with light brown rings. Length of femur: I 0.90, II 0.90, III 0.95, IV 1.70; patella + tibia: I 1.10, II 1.05, III 1.05, IV 1.95; metatarsus + tarsus: I 0.82, II 0.80, III 0.97 , IV 1.30. Abdomen dorsally dark brown with a pair of small cream spots on the anterior half and a pair of larger cream spots on the posterior half; slightly conspicuous chevrons extending from among these four cream spots to the posterior edge of abdomen; laterally and ventrally cream colored. Epigynum with a median atrium and short sinuous copulation ducts (Figs 7-8). Spinnerets as in the male.

Variation. Ten males: total length: 3.00-3.90; carapace length: 1.75-1.95. Four females: total length: 3.75-5.00; carapace length: 1.70-2.10.
Additional material examined. BRAZIL, Maranhão: Barreirinhas (Parque Nacional dos Lençóis Maranhenses), nine males and two females, 12-18.X.2001, Equipe Biota leg. (IBSP 5138451387; 51390; 51392-51393).

Distribution. Known only from the State of Maranhão, Brazil.

Natural history. The material examined was collected with pitfall traps in the Brazilian Cerrado, a phytogeographic region characterized by very old and deep soils and by a regular and moderate dry season. Temperatures range from $22^{\circ} \mathrm{C}$ to $25^{\circ} \mathrm{C}$, reaching $40^{\circ} \mathrm{C}$ and $10^{\circ} \mathrm{C}$ in summer and winter, respectively (RIzZINI 1997).

\section{Capeta cachimbo sp. nov. Figs 9-12}

Types. Male holotype from Brazil, Pará: Novo Progresso (Campo de Provas Brigadeiro Velloso, Serra do Cachimbo,

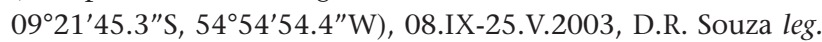
(MPEG 1367); two female paratypes with the same data as holotype (MPEG 1367; IBSP 51669, ex-MPEG 2102).

Etymology. The specific name is a toponymy in apposition. It is a Portuguese noun and means "smoking pipe".

Diagnosis. Specimens of Capeta cachimbo sp. nov. differ from those of $C$. tridens Ruiz \& Brescovit (2005: figs 21-22) by the stouter embolus of the male palp, which has no projection at the base (Figs 9-10). Females can be distinguished from those of C. tridens (Ruiz \& Brescovit, 2005: figs 23-24) by the shorter projection on the posterior border of the epigynal plate and internally by the presence of digitiform glands (Figs 11-12).

Description. Male. Total length: 4.25. Carapace light brown, 2.20 long, 1.65 wide, 1.05 high. Ocular quadrangle 0.95 long. Anterior eye row 1.40 wide and posterior 1.97 wide. Black rings around the eyes; a semicircular recurved dark brown stain in front of the fovea; a wide dark brown stripe extending from the fovea to the posterior edge of the abdomen, where it becomes wider; a pair of wide dark brown stripes extending laterally from the ocular quadrangle to the posterior edge; clypeus variegated, with long dark and short white hairs. Chelicera dark brown, with five teeth on promargin. Endite, labium and sternum yellow. Palp light brown, with a dorsal and a ventroretrolateral longitudinal row of long white hairs; cymbium elongated, embolus straight and stout, RTA acute and long and a reduced VTA (Figs 9-10). Legs 4132 yellow, with several sparse small dark brown spots, one of them enlarged on the median prolateral femur IV. Length of femur: I 1.00, II 1.00, III 1.00, IV 2.05; patella + tibia: I 1.35, II 1.15, III 1.07, IV 2.27; metatarsus + tarsus: I 1.00, II 0.90, III 1.00, IV 1.60. Abdomen cream, variegated with black, covered by a dark brown dorsal scutum, forming a dorsal disruptive pattern with three pairs of interconnected black stains; laterally variegated; cream with longitudinal dark brown stripes ventrally. Spinnerets brown.

Female. Total length: 4.05. Carapace light brown, 2.00 long, 1.57 wide, 1.00 high. Ocular quadrangle 1.00 long. Ante- 

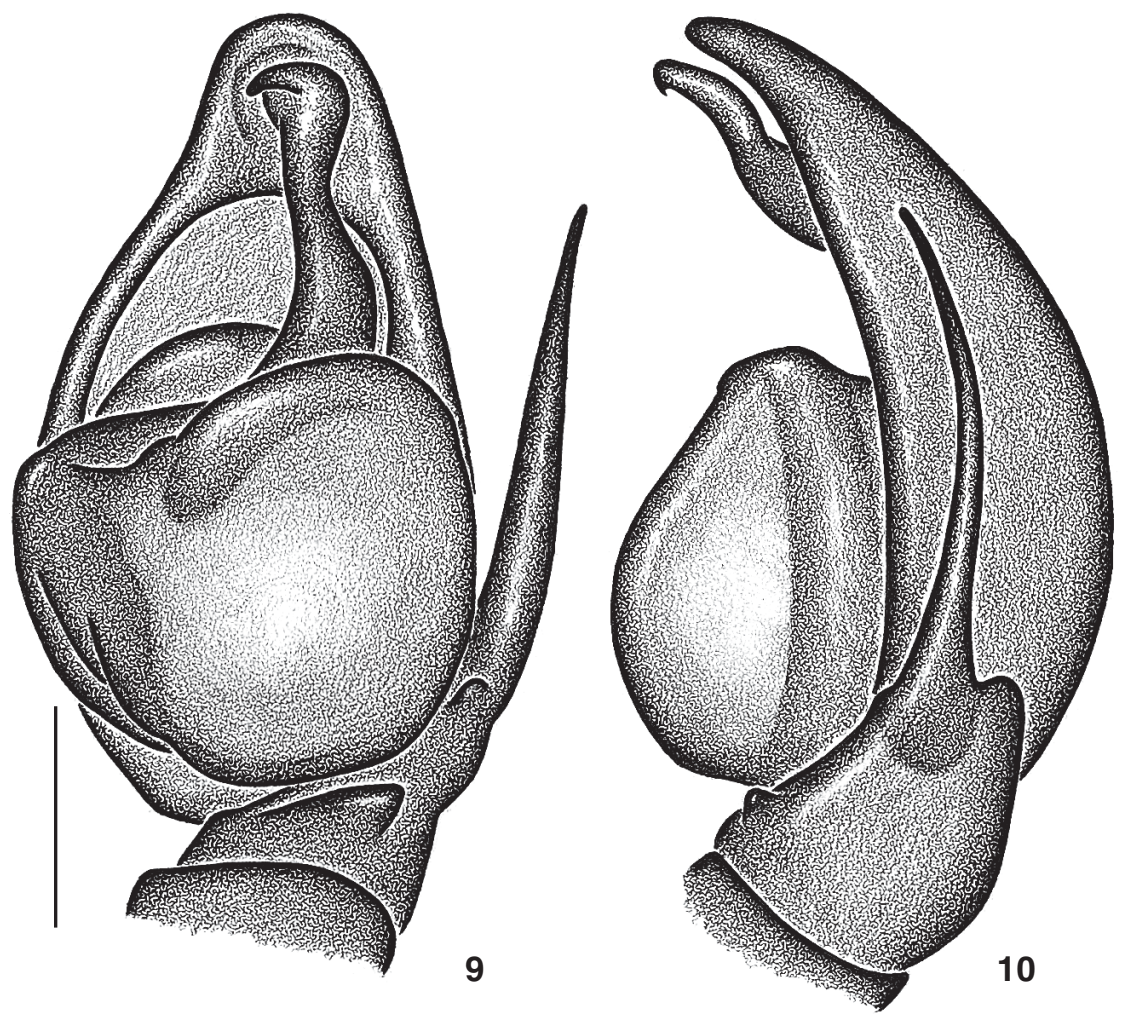
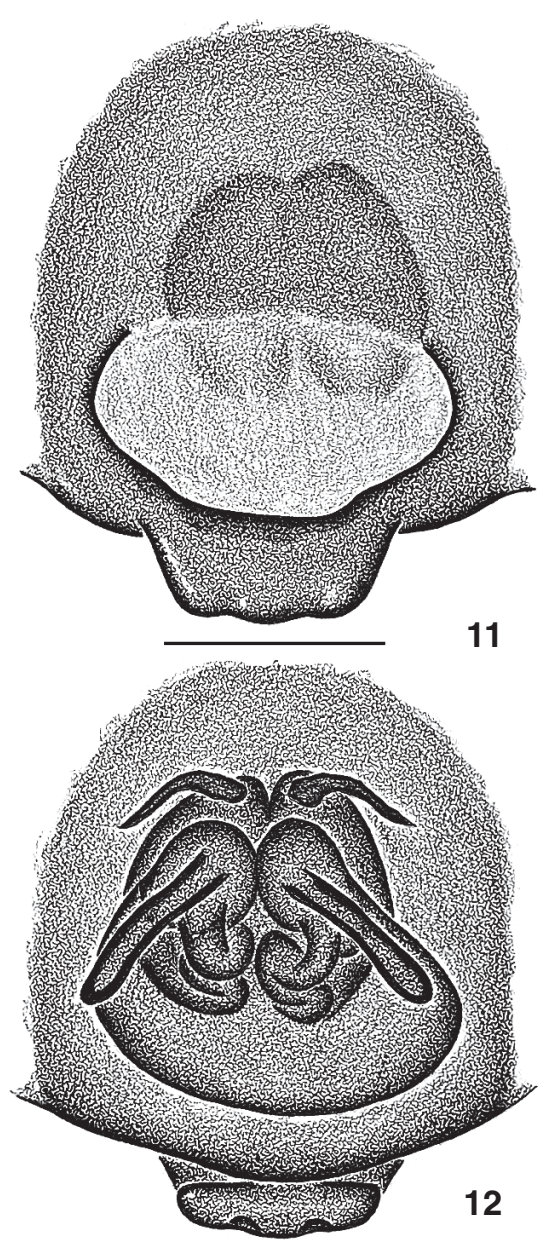

12

Figures 9-12. Capeta cachimbo sp. nov.: (9) male palp, ventral view, (10) retrolateral view; (11) epigynum, ventral view; (12) dorsal view. Scale lines: $0.25 \mathrm{~mm}$.

rior eye row 1.35 wide and posterior 1.45 wide. General coloration pattern as in the male, but lighter. Chelicera yellow, with five teeth on promargin. Endite, labium and sternum yellow. Palp yellow. Legs 4123 yellow, with less conspicuous spots than the male. Length of femur: I 0.95, II 0.90, III 0.87, IV 1.90; patella + tibia: I 1.20, II 1.05, III 0.95, IV 2.20; metatarsus + tarsus: I 0.87, II 0.80, III 0.90, IV 1.52. Abdomen as in the male, with a less conspicuous coloration pattern. Epigynum with a wide oval atrium and a short posterior projection; internally with a pair of long digitiform glands, toward sinuous copulation ducts and large spermathecae (Figs 11-12). Spinnerets yellow.

Variation. Four females: total length: 4.05-4.45; carapace length: 1.90-2.00.

Additional material examined. Brazil, Pará: Novo Progresso, Serra do Cachimbo, Campo de Provas Brigadeiro Velloso, two females, 08.IX-25.V.2003, D.R. Souza leg. (MPEG 2100; 2104).

Distribution. Known only from the State of Pará, Brazil.

\section{Amatorculus cristinae sp. nov.}

Figs 13-16

Types. Male holotype from BraziL, Pará: Novo Progresso (Campo de Provas Brigadeiro Velloso, Serra do Cachimbo, $09^{\circ} 21^{\prime} 45.3^{\prime \prime}$ S, 54 54'54.4"W), 08.IX-25.V.2003, D.R. Souza leg. (MPEG 2137); a female paratype from the same locality, 12.III11.IV.2004 (MPEG 1295).

Etymology. The species is named in honour of the Brazilian arachnologist Cristina A. Rheims.

Diagnosis. Specimens of Amatorculus cristinae sp. nov. differ from those of $A$. stygius Ruiz \& Brescovit (2005: figs 2526) by the longer ventral branch of the RTA (Fig. 14). Females can be distinguished from those of $A$. stygius (RuIz \& BRESCOVIT 2005: figs 27-28) by the elliptical atrium on the epigynal plate and by the straight copulation ducts (Figs 15-16).

Description. Male. Total length: 4.65. Carapace light brown, 2.32 long, 1.75 wide, 1.00 high. Ocular quadrangle 1.05

Revista Brasileira de Zoologia 23 (2): 350-356, junho 2006 

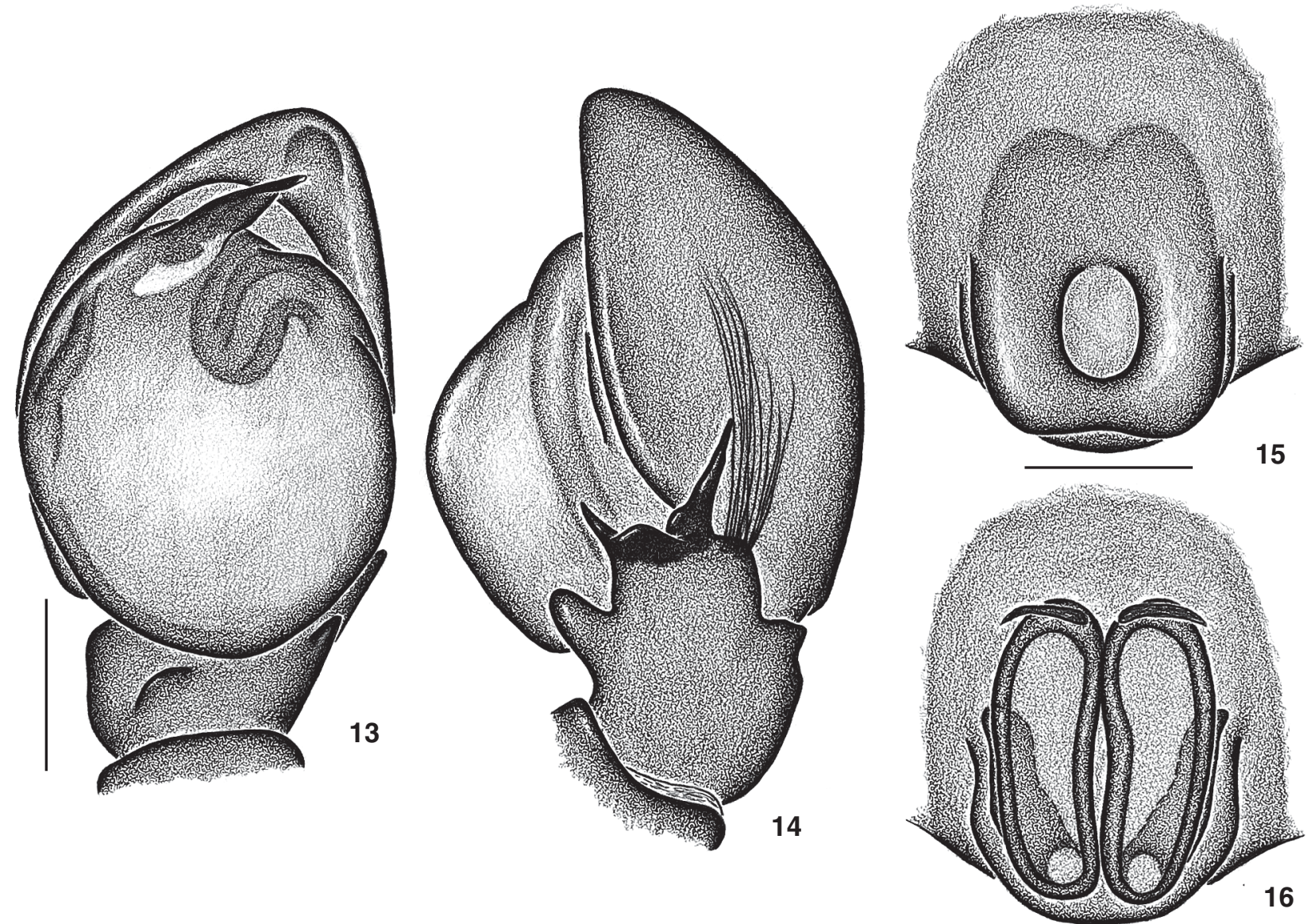

Figures 13-16. Amatorculus cristinae sp. nov.: (13) male palp, ventral view, (14) retrolateral view; (15) epigynum, ventral view; (16) dorsal view. Scale lines: $0.25 \mathrm{~mm}$.

long. Anterior eye row 1.50 wide and posterior 1.52 wide. Black rings around the eyes; a wide longitudinal dark brown stripe extending from the fovea to the posterior edge of the abdomen; laterally variegated; clypeus with white hairs. Chelicera dark brown, with five teeth on promargin. Endite, labium and sternum yellow. Palp with a short embolus, spherical tegulum, bifid RTA and a rounded VTA (Figs 13-14). Legs 4132 yellow, with three longitudinal dark stripes dorsally on femora, more conspicuous on femur IV; a pair of longitudinal dark stripes prolaterally on patellae and tibiae I and II and ventrally on patellae and tibiae III and IV; a median light brown stain prolaterally on femur IV. Length of femur: I 1.17, II 1.10, III 1.15, IV 2.25; patella + tibia: I 1.40, II 1.15, III 1.15, IV 2.45; metatarsus + tarsus: I 1.05, II 0.95, III 1.05, IV 1.75. Abdomen cream colored, variegated with black, covered by a dark brown dorsal scutum, forming a dorsal disruptive pattern with three pairs of interconnected black stains; laterally variegated, ventrally cream. Spinnerets brown.

Female. Total length: 3.75. Carapace light brown, variegated, 1.90 long, 1.50 wide, 0.92 high. Ocular quadrangle 0.95 long. Anterior eye row 1.00 wide and posterior 1.35 wide. Cara- pace coloration pattern as in the male, but lighter. Chelicera yellow, with five teeth on promargin. Endite, labium and sternum yellow. Palp yellow. Legs 4132 yellow, coloration pattern less conspicuous than that of the male. Length of femur: I 1.42, II 1.40, III 1.40, IV 1.75; patella + tibia: I 1.07, II 0.95, III 0.90, IV 1.90; metatarsus + tarsus: I 0.80, II 0.75, III 0.80, IV 1.40. Abdomen cream colored, totally variegated with black. Epigynum with an elliptical median atrium, straight copulation ducts and large spermathecae (Figs 15-16). Spinnerets dark brown.

Distribution. Known from the State of Pará, Brazil. Additional material examined. None.

\section{Amatorculus stygius Ruiz \& Brescovit, 2005}

Amatorculus stygius Ruiz \& Brescovit, 2005: figs 25-28.

New record. Brazil, Minas Gerais: Santana do Riacho, Parque Nacional da Serra do Cipó $\left(19^{\circ} 15^{\prime} \mathrm{S}, 43^{\circ} 31^{\prime} \mathrm{W}\right)$, one female, 07-14.X.2002, Equipe Biota leg. (IBSP 51665).

Distribution. Known from the Distrito Federal and from the States of São Paulo and Minas Gerais, Brazil.

Revista Brasileira de Zoologia 23 (2): 350-356, junho 2006 


\section{ACKNOWLEDGMENTS}

We wish to thank CNPq (Conselho Nacional de Desenvolvimento Científico e Tecnológico) and FAPESP (Fundação de Amparo à Pesquisa do Estado de São Paulo, 99/05446-8 and 03/02556-4) for the financial support. We also thank G.B. Edwards, Cristina A. Rheims and Arno A. Lise for helpful suggestions on the manuscript. This study is part of the BIOTA/ FAPESP - the Biodiversity Virtual Institute Program (www.biotasp.org.br).

\section{REFERENCES}

Fernandes, A. 1998. Fitogeografia Brasileira. Fortaleza, Multigraf, 340p.

Recebido em 09.VI.2005; aceito em 06.IV.2006.
Galiano, M.H. 1987. Description of Aillutticus, new genus (Araneae, Salticidae). Bulletin of the British Arachnology Society, Dorset, 7 (5): 157-164.

Joly, C.A.; M.P.M. Aidar; C.A. Klink; D.G. McGrath; A.G. Moreira; P. Moutinho; D.C. Nepstad; A.A. Oliveira; A. Pott; M.J.N. Rodal \& E.V.S.B. SAmpaIO. 1999. Evolution of the Brazilian phytogeography classification systems: Implications for biodiversity conservation. Ciência e Cultura, São Paulo, 51: 331348.

RizzinI, C.T. -1997. Tratado de fitogeografia do Brasil. Rio de Janeiro, Âmbito Cultural Edições, $2^{a}$ ed., 747p.

RuIz, G.R.S. \& A.D. BRESCOVIT. 2005. Three new genera of jumping spider from Brazil (Araneae, Salticidae). Revista Brasileira de Zoologia, Curitiba, 22 (3): 687-695. 